\section{How to Write a Scientific Paper: Three Tips to Remember}

\author{
Kun Hwang \\ Department of Plastic Surgery, Inha University School of Medicine, Incheon, Kroea
}

Correspondence: Kun Hwang

Department of Plastic Surgery and the Center for Advanced Medical Education by the BK21 Project, Inha University School of Medicine, 27 Inhang-ro, Jung-gu, Incheon 400-711, Korea

Tel: +82-32-890-3514, Fax: +82-32-890-2918, E-mail: jokerhg@inha.ac.kr

No potential conflict of interest relevant to this article was reported.

Received: 10 Dec 2011 • Revised: 15 Dec 2011 • Accepted: 22 Dec 2011 pISSN: 2234-6163 • elSSN: 2234-6171 http://dx.doi.org/10.5999/aps.2012.39.1.77A • Arch Plast Surg 2012;39:77

Copyright (C) 2012 The Korean Society of Plastic and Reconstructive Surgeons This is an Open Access article distributed under the terms of the Creative Commons Attribution Non-Commercial License (http://creativecommons.org/licenses/by-nc/3.0/) which permits unrestricted non-commercial use, distribution, and reproduction in any medium, provided the original work is properly cited.

In the field of plastic surgery, many new ideas and skills are developed by surgeons and researchers. "Publish or perish" is a phrase coined to describe the pressure in academia to publish work constantly to further or sustain one's career [1]. To share knowledge or skill with others, or promote one's position in schools, they should write papers. However, it is not easy to gather and develop writing material.

I learned an invaluable lesson at the International Confederation of Plastic, Reconstructive, and Aesthetic Surgery meeting which was held in Yokohama, Japan in 1995. At the opening ceremony, Dr. Joseph Murray who performed the first successful human kidney transplant on identical twins and who shared the Nobel Prize in Physiology or Medicine had the keynote lecture.

The elder retired plastic surgeon emphasized that scientists should remember 3 important words: curiosity, imagination, and persistence. Curiosity is an emotion related to natural inquisitive behavior such as exploration, investigation, and learning. We can have curiosity in any basic research or about surgical procedures. Imagination is the ability to form mental images, sensations and concepts, in a moment when they are not perceived through sight, hearing, or the other senses. Lastly, persistence is the determination to do something even though it is difficult or other people oppose it.

Reading a book about swimming cannot guarantee the ability to swim. Likewise, there is no royal road to writing papers. However, it would be helpful to the surgeon to remember Dr. Murray's 3 words: curiosity, imagination, and persistence.

\section{Reference}

1. Neill US. Publish or perish, but at what cost? J Clin Invest 2008;118: 2368 .

\section{Sural Intraneural Ganglion Cysts Are Joint-related}

Robert J. Spinner ${ }^{1,2}$, Kimberly K. Amrami ${ }^{1,3}$, Mohanad Ahmed Ibrahim Elshiekh ${ }^{1}$, Neal M. Blitz ${ }^{4}$

Departments of ${ }^{1}$ Neurologic Surgery, ${ }^{2}$ Orthopedics, and ${ }^{3}$ Radiology, Mayo Clinic, Rochester; ${ }^{4}$ Department of Orthopedic Surgery, Bronx-Lebanon Hospital Center, Bronx, USA

Correspondence: Robert J. Spinner

Departments of Neurologic Surgery, Orthopedics, Mayo Clinic, Gonda 8-214 South, Rochester, MN 55905, USA

Tel: +1-507-284-2376, Fax: +1-507-284-5206, E-mail: spinner.robert@mayo.edu

No potential conflict of interest relevant to this article was reported.

Received: 8 Nov 2011 • Revised: 15 Dec 2011 • Accepted: 28 Dec 2011 pISSN: 2234-6163 • elSSN: 2234-6171

http://dx.doi.org/10.5999/aps.2012.39.1.77B • Arch Plast Surg 2012;39:77-79

Copyright ( $(2012$ The Korean Society of Plastic and Reconstructive Surgeons

This is an Open Access article distributed under the terms of the Creative Commons Attribution Non-Commercial License (http://creativecommons.org/licenses/by-nc/3.0/) which permits unrestricted non-commercial use, distribution, and reproduction in any medium, provided the original work is properly cited.

The recent article by Kim and Kim [1] provides a valuable case of a rare sural intraneural ganglion cyst to the literature. We offer yet another example to highlight recent developments in our understanding of this entity.

A 42-year-old woman presented with a 6 month history of the spontaneous onset of moderately severe pain developing in the right lateral rearfoot in the retrolateral malleolar region with radiating dysesthesias into the dorsolateral foot. Symptoms were worse with standing or with activity. Exam revealed a $3 \times 2 \mathrm{~cm}$ soft tissue tubular mass along the course of the sural nerve which had features consistent with a ganglion cyst. It was tender to palpation. Percussion produced radiating paresthesias in the sural nerve distribution. Sensation was intact on the dorsal foot to light touch. Magnetic reconance imaging (MRI) demonstrated a sural intraneural ganglion cyst with a joint connection to the subtalar joint (Figs. 1, 2). At operation, this articular branch connection was identified, ligated and resected. The patient had full recovery immediately postoperatively; there was no clinical evidence of persistent pain or cyst at last follow-up examination.

As Kim and Kim [1] point out, the pathogenesis of these cysts has been controversial and poorly understood. Recent reports have clarified this. Layers of robust evidence have substantiated an articular origin for all types of intraneural cysts first at the prototypic site (the common fibular nerve) and then at other joints throughout the appendicular skeleton and axial spine [2,3]. The unifying articular (synovial) theory has been shown to be generalizable and universal. Joint connections must be assumed to be present. We have emphasized the difficulties in identifying the joint connection with imaging and at operation. Experience with both can reliably and reproducibly identify the joint connection. High resolution imaging (MRI or computed tomography imaging with or without arthrography; 